\title{
Law, justice and rights: some implications of a global perspective
}

\author{
WILLIAM TWINING
}

\section{Jurisprudence}

In academic life there is a widespread tendency for bodies of literature to talk past each other. This seems to be the case with much of the literature on environmental law, environmental justice, mainstream jurisprudence, and globalisation. This chapter suggests some chasms and some connections between them, and relates to the question: "What are the implications of so-called "globalisation" for the institutionalised discipline of law and especially for jurisprudence, conceived as the theoretical or more general part of that discipline?' ${ }^{1}$ I shall reflect on a number of themes, concepts, and distinctions that are broadly relevant to debating issues about environmental justice in today's world: including the nature of theorising about law; the discourses of globalisation; picturing law from a global perspective; normative jurisprudence, especially theories and discourses of justice and human rights.

I treat jurisprudence as the theoretical or more abstract part of law as a discipline. ${ }^{2}$ Philosophy of law is the most abstract part of jurisprudence, which is also concerned with a wide range of theoretical issues that are not primarily philosophical. Jurisprudence can be conceived of as both a heritage and an activity. Western jurisprudence has a vast heritage of texts, questions, answers, and arguments. It can also be conceived of as an activity directed to posing, reposing, reflecting on, hypothesising answers to, and arguing about these questions.

In the Anglo-American tradition the heritage and the activity are sometimes classified into broadly defined, but overlapping, fields: Julius Stone categorised them as analytical jurisprudence, sociological (or functional) jurisprudence, and theories of human law and justice (censorial, critical, or ethical). ${ }^{3}$ I prefer to talk rather more broadly of analytical, normative, empirical (or socio-legal), and critical jurisprudence. Such classifications serve a modest purpose provided that two points are born in mind:

1 This presents in succint form themes that are developed at greater length in Twining, General Jurisprudence (2008). See also Twining (1997, 2000, 2003a, 2003b, 2003c, 2005b, 2005c). I am grateful to Andrew Halpin, Jonas Ebbesson, and John Tasioulas for helpful comments and suggestions.

${ }^{2}$ Twining (1997) at 110-14. $\quad{ }^{3}$ Stone (1946) Ch. 1 (discussed in Twining (2003a)). 
first, the boundaries between these activities are not precise and are often contested; and, secondly, most practical questions about law involve a combination of analytical, empirical, and normative elements. So any classification of these broad fields or activities should not be expected to bear much weight. ${ }^{4}$

If one stands back and surveys the vast heritage of Western legal theorising about law, one is reminded of two tendencies that are in tension. First, the Western heritage is vast. However, viewed from a global perspective, that same heritage can be criticised for being insular, parochial, quite narrowly focused, and even ethnocentric. Nearly all of it concentrates on the municipal law of sovereign states, mainly those in advanced industrial societies; it operates within and across only two of the world's major legal traditions, common law and civil law, with other major traditions marginalised or completely ignored. The 'Country and Western tradition' of legal theorising and comparative law is vulnerable to charges of parochialism and ethnocentrism. ${ }^{5}$

\section{Globalisation and G-talk}

Words like 'globalisation' and 'global' are used very loosely. Here, it is useful to distinguish between two primary uses. First, 'globalisation' is sometimes used to refer to certain recent tendencies in political economy - the domination of the world economy by a group of interrelated ideologies and practices, sometimes referred to as 'the Washington Consensus'. This usage is clearly illustrated by 'the anti-globalisation' movement, which has rather diffuse targets, including American hegemony, Western dominated international financial institutions, free market ideology, and capitalism in general. The issues are important, not least in respect of environmental matters, but this usage is too narrow in the present context. I shall use the term 'globalisation', following Anthony Giddens, in a much broader, less politically fraught sense, to refer to those processes that increase interaction and interdependence in respect of not only economy and trade, but also communications, science, technology, language, travel, migration, ecology, climate, disease, war and peace, security and so on. ${ }^{6}$

This second broader meaning can be quite useful, but it too is problematic. Terms such as global corporations, global law, global lawyers, global law firms, and global jurisprudence are indicative of a tendency to make exaggerated, misleading, meaningless, superficial, ethnocentric, or just plain false generalisations about processes and phenomena that are better discussed in less hyperbolic terms. ${ }^{7}$ In particular, it is worth emphasising three points that are particularly pertinent to law.

(i) Lawyers need to be especially sensitive to boundaries, jurisdictions, and levels of ordering. Not only are national boundaries becoming more porous, but we are all

${ }^{4}$ Hart (1983) at 88-9. $\quad 5$ Twining (2000) at 184-9.

${ }^{6}$ Giddens (1990) at 64. See further Twining (2000) Ch. 1, at 4-10.

7 Most global generalisations, even if true, refer to surface phenomena. In a sense, it may be true that Holiday Inns or CNN or British Airways circle the world, but these refer to surface phenomena that may conceal more than they reveal. This theme is developed in Twining (2008) Ch. 10, 'Surface Law'. 
familiar with the idea of different levels of ordering - for example, the differences between general public international law (some of which is genuinely global), regional, state, sub-state, and so on. We are also familiar with the elusiveness of subsidiarity and margins of appreciation. But other complexities are often overlooked. For example, there is a tendency to move back and forth between the global and the local, not only leaving out intermediate levels but also implicitly accepting a picture of levels of law as being stacked in a single neat vertical hierarchy from outer space, through global, regional, and national down to the very local. But there are important legal patterns that are geographically more complex than that: for example, the Jewish and Islamic diasporas, the former European empires, the common law world, the British Commonwealth, NATO, OPEC, and other alliances, networks, religions, cartels, spheres of influence - all of these cut across simple vertical hierarchies and greatly complicate the picture of patterns of ordering and the diffusion of legal ideas.

(ii) Not all interaction between legal orders takes place at one level. Comparative law and studies of legal transplants have tended to focus on the relationship between different state legal systems and to neglect other aspects of interaction - cross-level diffusion, different forms of interlegality and, above all, legal and normative pluralism are now central concerns as the discipline of law becomes more cosmopolitan. ${ }^{8}$

(iii) Talk of 'levels' of relations and of ordering involves spatial metaphors that are not always appropriate in respect of law. There is a developing sub-field of law and geography and the idea of mapping law has its uses. Gordon Woodman has forcefully argued that state law is typically defined in terms of relatively determinate territory, but many laws and legal orders are not. ${ }^{9}$ This is especially the case with personal and religious laws. Similar arguments apply to 'spheres of justice. ${ }^{10}$ The point is valid. However, if we conceive of law as a form of institutionalised social practice and if we are concerned with the law in action, then we are dealing with actual behaviour, which does take place at particular times in particular places. For example, if we agree that shari'a travels with every devout Muslim, a good map of Islamic diasporas can at least give a general indication of where Islamic law is likely to exist at a given time as an institutionalised social practice. ${ }^{11} \mathrm{We}$ need to guard against overusing spatial metaphors, but there is still scope for legal geography. ${ }^{12}$

Of course, there are genuinely global phenomena and issues that are or should be of concern to all humankind, such as climate change, nuclear proliferation, war and peace, radical poverty, and the exploration and exploitation of outer space. But even

\footnotetext{
8 Twining (2000) at Ch. $6 . \quad{ }^{9}$ Woodman (2003). $\quad{ }^{10}$ Singer (1983).

${ }^{11}$ On Islamic law in England as a form of custom that has slowly influenced English municipal law, see Pearl and Menski (1998) especially Ch. 3.

12 Blomley (1994), Economides (1996), Holder and Harrison (2003).
} 
then there are still important questions about what are the most appropriate levels of policy and law for dealing with each issue.

\section{A global perspective}

If one is sensitive to different levels of relations and of ordering, then a global perspective can serve as much to emphasise diversity and complexity as to simplify. Thinking globally at least sets a context for focusing at other levels. A quick way in is to consider the limitations of a map of law that is confined to municipal legal systems, i.e. the domestic law of nation states. There are some obvious criticisms to be made:

(i) A map confined to national legal systems leaves out other levels of supranational, subnational and transnational levels of legal relations: public international law, European Commmunity law, Islamic law, Maori law, and lex mercatoria for example. (ii) It leaves out some of the major legal traditions in which law is not conceptually or politically tied to the idea of the state. For example, it leaves out Islamic law or confines it to countries in which Islamic law is formally recognised as a source of municipal law. But it is obvious that this distorts the extent, scope, and nature of shari'a. (iii) However, if we decide to include major religious and customary normative orderings, and perhaps other examples of non-state law, we run into major conceptual problems. First, we have to adopt a conception of law that includes at least some examples of 'non-state law'. That reopens the Pandora's box of the problem of the definition of law and all its attendant controversies. ${ }^{13}$ Secondly, there is the problem of individuating legal orders. What counts as one legal order or system or unit for the purposes of mapping? How does one deal with vaguely constituted agglomerations of norms, which may be more like waves or clouds than billiard balls? ${ }^{14}$ (iv) If one decouples the notion of law and state, one is confronted with another set of problems. If one moves away from the idea of one kind of institution having a legitimate claim to monopoly of authority and force, one has to accept the idea of legal and normative pluralism - i.e. the coexistence of more than one legal order in the same time-space context - and all the difficulties that entails.

\section{Analytical and empirical jurisprudence: some brief comments}

The topic of environmental justice prima facie falls within the province of normative jurisprudence. But, because most legal discourse, scholarship, and debate involve conceptual, factual, technical, and normative (i.e. ethical and evaluative) dimensions, it is useful to make some other general points about the implications of adopting a global perspective for legal theory and the discipline of law and for sub-fields, such as environmental law.

\footnotetext{
13 Twining (2003b). $\quad{ }^{14}$ Ibid.
} 
(i) Analytical jurisprudence. Conceptual analysis is one important aspect of analytical jurisprudence. ${ }^{15}$ Adopting a global perspective highlights the need for adequate analytical concepts that can transcend different legal cultures and traditions. Because traditional legal scholarship was mainly confined to domestic law and most analytical jurists have focused on the concepts of legal doctrine (e.g. legal rights, ownership, causation) and its presuppositions (rules, legal system, validity), the focus has been mainly on law talk rather than talk about law. The doctrinal concepts of a legal system (such as English law) or a legal culture (such as the common law) are mainly 'folk concepts' with limited transferability across legal cultures and traditions. Conceptual elucidation is just as important for socio-legal studies as it is for legal analysis and exposition. But concepts such as dispute, institution, process, function, impact, and even court have been relatively neglected. Precise well-developed analytical concepts are needed for making comparisons and generalisations about legal phenomena across legal systems, traditions, and cultures. Our stock of usable transferable concepts is limited, so is our bank of reliable comparative empirical data. So our capacity to make comparisons and generalisations across legal cultures and tradition is correspondingly limited.

(ii) Empirical jurisprudence. Most socio-legal and empirical studies of legal phenomena have been confined to a single society, even in regard to non-state law. Recently, comparative and transnational empirical legal studies have started to develop, but the field is still at a relatively primitive stage. From a global perspective, one of the most important topics in need of empirical research is what social scientists call the processes of diffusion - often referred to by lawyers as transplants or reception. I have argued elsewhere that legal writings about this subject have tended to be unempirical and have been unduly influenced by 'a naïve model of reception'. ${ }^{16}$ This is an 'ideal type', which postulates a paradigm case with the following characteristic assumptions:

\begin{abstract}
[A] bipolar relationship between two countries involving a directone-way transfer of legal rules or institutions through the agency of governments involving formal enactment or adoption at a particular moment of time (a reception date) without major change... [I]t is commonly assumed that the standard case involves transfer from an advanced (parent) civil or common law system to a less developed one, in order to bring about technological change ('to modernise') by filling in gaps or replacing prior local law. ${ }^{17}$
\end{abstract}

It is easy to show that none of these elements is necessary or even characteristic of actual processes of diffusion of law, which are much more diverse and complex than the 'naïve model' suggests. This is relevant in the present context because so many environmental problems involve cross-level interactions between different state and

\footnotetext{
15 This argument is developed in Twining (2008), Ch. 2. $\quad{ }^{16}$ Twining (2005b) and (2005c). ${ }^{17}$ Ibid.
} 
non-state legal orders and the development of environmental law and justice involves diffusion of ideas developed at many different levels.

\section{Adjusting the canon: filleting Hart, extending Bentham, realising Rawls}

If one accepts the points about the importance of differentiating levels of ordering, about the significance of non-state law, and about legal pluralism, this raises some important questions about the relevance of twentieth-century canonical jurists to considering law and justice from a global perspective. For example, most of the leading Western jurists of the twentieth century have focused very largely on municipal state law, have had strong conceptions of sovereignty, and have assumed that legal systems and societies can be treated as discrete, largely self-contained units. They have either articulated or assumed that jurisprudence and the discipline of law is or should be concerned with only two kinds of law: the domestic municipal law of nation states and public international law, which was widely accepted as a secondary form of law, mainly concerned with relations between states ('the Westphalian Duo').

At first sight, this suggests that many of these canonical jurists have become outdated and irrelevant. However, a younger generation of theorists has begun to adjust the Western liberal tradition in ways that suggest that, with due modifications, some twentieth-century canonical jurists are of continuing relevance.

For example, Brian Tamanaha, stayed with Hart's two basic positivist premises the separation thesis and the social sources thesis - but pared away all Hart's criteria of identification in order to construct a broadened conception of law that would include several forms of non-state and religious law, but which differentiated it from other social rules and institutions, such as those involved in the governance of hospitals, schools, and sports leagues. ${ }^{18}$

Thomas Pogge, a pupil of Rawls, has argued that Rawls' two principles of justice (somewhat modified) can be transferred directly to the international sphere, largely by challenging the idea of a society as a self-enclosed unit. ${ }^{19}$ Pogge has been sharply critical of Rawls' attempts to limit his principles of justice to the domestic sphere. ${ }^{20}$ Pogge has transformed what had increasingly come to be seen as a rather complacent and conservative theory of domestic justice into a quite radical theory as the basis for a sharp critique of the existing international order and its institutions. I shall return to Pogge in due course.

In a somewhat different way, Peter Singer has applied Benthamite utilitarianism to contemporary issues in international ethics, including environmental ethics. ${ }^{21}$ Jeremy

18 Tamanaha (2001), discussed in Twining (2003b). ${ }^{19}$ Pogge (1989), (2002), discussed below.

${ }^{20}$ Rawls (1971) at 378-82, developed in Rawls (1999b). Pogge's original criticism was directed to the treatment of transnational ethics in A Theory of Justice, but later he developed and extended his critique (especially, Pogge (2001) and (2002)).

21 Especially Singer (1975/1990); cf. Singer (1972), (1993) and (2004). 
Bentham prided himself in being 'a citizen of the world', he coined the term 'international law', but has generally been interpreted as a theorist of strong sovereignty. ${ }^{22}$ Bentham posed the question whether the sovereign's duty is to maximise the interests of his own people or of humankind as a whole ? $^{23}$ Bentham did not really answer this question, but Peter Singer, who is widely considered to be the leading contemporary proponent of classical utilitarianism, has come out firmly in favour of the idea that national leaders owe a duty to humankind, even though this presents problems when democracy is largely confined to some nation states. ${ }^{24}$

Thus, already there are jurists who are reworking our heritage of legal thought to adjust to the changing global scene. In rather different ways, Patrick Glenn could be interpreted as reviving an earlier tradition of world history applied to law $^{25}$ and Boaventura de Sousa Santos could be viewed as a post-modern successor to Weber and Marx. ${ }^{26}$

\section{Normative jurisprudence}

Normative jurisprudence encompasses general questions about values and law. It deals with the relations between law, politics and morality, including debates between and among positivists and others about the relationship between law and morals, whether law is at its core a moral enterprise, and about political obligation and civil disobedience. It includes questions about the existence, scope and status of natural, moral and non-legal rights; the relationship between needs, rights, interests, and entitlements; theories of justice; constitutionalism and democracy; and standards for guiding and evaluating legal institutions, rules, practices, and decisions. Normative jurisprudence now occupies a central place on the agenda of Anglo-American jurisprudence.

If one steps back and considers the Western heritage of normative jurisprudence from a global perspective, one can identify a number of tendencies that are relevant to discussing issues of environmental justice.

\subsection{The collective ignorance of other traditions}

As with other branches of jurisprudence, Western normative jurisprudence has been quite insular. Western jurisprudence has a long tradition of universalism in ethics.

22 See generally Dinwiddy (2004). On Bentham's subtle analysis of sovereignty, see Hart (1982) Ch. IX.

23 J. Bentham (1806-9) discussed in Twining (2003a) at 237-42.

24 'This book argues that as the nations of the world move closer together to tackle global issues like trade, climate change, justice, and poverty, our national leaders need to take a larger perspective than that of national self-interest.' Singer (2004) (preface to second edition). While a utilitarian, such as Singer, would argue for harmonising national and global interests, the scope of a locally elected leader's duty to humankind needs further development.

25 Glenn (2004), discussed in Foster (2006).

26 Santos (2002). The first edition, Santos (1995), is discussed in Twining (2000) Ch. 8. 
Natural law, classical utilitarianism, Kantianism, and modern theories of human rights have all been universalist in tendency. ${ }^{27}$ But nearly all such theories have been developed and debated with at most only tangential reference to and in almost complete ignorance of the religious and moral beliefs and traditions of the rest of humankind. When differing cultural values are discussed, even the agenda of issues has a stereotypically Western bias. How can one seriously claim to be an informed universalist if one is ethnocentrically unaware of the ideas and values of other belief systems and traditions?

As the discipline of law becomes more cosmopolitan it needs to be backed by a genuinely cosmopolitan general jurisprudence. To this end we need to adjust the conventional canon of juristic texts to include significant writings and salient ideas and controversies from other traditions or which represent other viewpoints. Until now this has been considered the province of specialists. The task is daunting, but not impossible. Despite criticisms of 'orientalism', there has been some excellent work by Western scholars on Islamic, Hindu, Bhuddist, and Chinese legal thought. ${ }^{28}$ To a lesser extent, there are accessible writings by contemporary 'Southern' writers. As a modest first step I have considered the general approaches to human rights of four 'Southern' jurists: Francis Deng, Abdullahi An Na'im, Yash Ghai, and Upendra Baxi. ${ }^{29}$ All four deserve to be better known, but this is a limited exercise as these particular ones were all trained in the common law, write in English, and belong to the immediate post-independence generation. There are many others, including not least Southern feminists, and prominent jurists whose work has not been translated into English.

\subsection{Secularism and a world-wide religious revival}

During the twentieth century Western normative jurisprudence has been dominated by three main types of ethical theory: utilitarianism, deontology (including Natural Law and Kantian theories of justice and human rights), and virtue ethics. ${ }^{30}$ These have, of course, been subjected to persistent challenges from various forms of scepticism, relativism, subjectivism, post-modernism, and, lately, in a different way, communitarianism. Eco-centric theories of environmental ethics could also be interpreted to fall outside the mainstream. ${ }^{31}$ Apart from Natural Law, nearly all of our stock of normative theories are explicitly or implicitly secular. Classical utilitarianism and consequentialism, Rawlsian justice, and most variants on these have their roots in post-Enlightenment rationalism. Human rights is sometimes presented as a form of secular liberation theology ${ }^{32}$ or as an ethical theory for a Godless Age. ${ }^{33}$

\footnotetext{
27 'Universalism' is a highly ambiguous concept. Here it will suffice to use it to refer to claims that a given moral principle applies to all humans at all times and in all places.

28 There are useful select bibliographies in Glenn (2004) and Huxley (2002).

29 Twining (2006) and (2008), Ch. 13. ${ }^{30}$ Griffin (1996) Ch. VII. ${ }^{31}$ See below.

32 Baxi (2006). $\quad{ }^{33}$ E.g. Gearty (2006) and Klug (2000).
} 
That we live in a secular age may be true of, say, most of the United Kingdom and of most, but not all, of Europe; but the rising visibility of religious minorities may soon change that perception here. It is not true of the United States. The reverse is true of the rest of the world, which is more appropriately characterised as going through a period of religious revival, some but not all of which is characterised by some quite aggressive and evangelical kinds of fundamentalism. This refers not only to the headline-catching spread of fundamentalism in Islam, but also to Christianity, as Philip Jenkins' important book The Next Christendom vividly portrays. ${ }^{34}$ From this perspective, secular liberalism appears to be on the decline and is beginning to look 'distinctly dated'. 35

From a global perspective, a central challenge to human rights is to provide a vision that is attractive not only to non-believers, but also to believers, be they Christians, Muslims, Hindus, or others. It needs to be shown to be compatible with their core religious beliefs, as Abdullahi an Na'im, and other committed Muslims, are trying to do. 36

\subsection{Belief Pluralism}

A third tendency in Western normative jurisprudence has been that leading liberal thinkers have beaten a partial retreat into an odd kind of particularism. ${ }^{37}$ Ronald Dworkin states that interpretive theories are by their nature addressed to a particular legal culture, generally the culture to which their authors belong. ${ }^{38}$ Similarly, John Rawls has stated that ' $[\mathrm{t}]$ he aims of political philosophy depend on the society it addresses, ${ }^{39}$ and went quite close to acknowledging that his project was to develop a criterion of justice that would appeal to reflective Americans. ${ }^{40}$ Whereas in A Theory of Justice there is a consensus among its members about the appropriate moral basis for a well-ordered democratic society, Political Liberalism confronts the problem of belief pluralism.

In response to this new concern, Rawls insisted that 'justice as fairness is political, not metaphysical. ${ }^{41}$ It is a practical theory aimed at providing a moral foundation for political, social, and economic institutions in a modern constitutional democracy in which the members have diverse, incompatible views. It is not a metaphysical or epistemological theory dealing with universal moral conceptions; nor does it apply

\footnotetext{
${ }^{34}$ Jenkins (2002). Cf. Miztal and Sharpe (1992). $\quad{ }^{35}$ Jenkins (2002) at 9.

36 E.g. An Na'im (1990), Lindholm and Vogt (1993).

37 MacIntyre (1985), Hampshire(1989). $\quad 38$ Dworkin (1986) at 102.

39 See generally Rawls (1971), Rawls (1993), Rawls (1999b), and Rawls (1999a). Especially important in the present context are three papers: Rawls (1980) (see now Rawls (1993), Lecture III); Rawls (1985) (see also Rawls (1993), Lecture I, 'Fundamental Ideas'); and Rawls (1987) (reprinted in Rawls (1999a) Ch. 20).

40 Rawls (1980) at 518-19.

41 Rawls (1985) at 226. Cf. Joseph Raz on Rawls' 'epistemic abstinence' in Raz (1994) at 62.
} 
to all societies. ${ }^{42}$ It is a limited secular theory that can provide a basis for coexistence and cooperation in a diverse society independently of religious beliefs and ideologies. A key idea is that of an overlapping consensus: this does not refer to those doctrines that are common to the different belief systems in a given society, but rather to what free and equal citizens would accept as a freestanding political view of society as a fair system of cooperation. ${ }^{43}$

This aspect of political liberalism is clearly relevant when we think about the institutions and practices needed for coexistence and cooperation in a world characterised by a diversity of belief systems, traditions, and cultures. On most interpretations of 'globalisation', which emphasise interdependence, the decline of sovereignty, and the permeability of borders, only one such society exists: the world. A well-constructed and coherent political theory which provides a coherent moral basis for the design of structures and institutions that can ensure stable, orderly, and fair arrangements for coexistence and cooperation between its diverse members is badly needed. In light of the critical issues of radical poverty, environmental crises, and increasing inequalities, a theory that claims to deal with global justice is especially welcome.

\subsection{Moving beyond domestic justice}

In recent times, liberal democratic political and legal theories have tended either to be geographically indeterminate or to place some limits on their geographical claims. A great deal of recent Anglo-American normative jurisprudence has been relatively local in respect of provenance, audience, and even focus. ${ }^{44}$ For example, most writings about the new communitarianism, critical race theory, and republicanism have been explicitly or implicitly or unself-consciously American or at least American-influenced. ${ }^{45}$ Feminist jurisprudence has only recently begun to be genuinely transnational. ${ }^{46}$

42 Rawls (1985). Justice as fairness is mainly concerned with individual liberty and distribution. Rawls deals only briefly with procedural justice, expletive justice (under the Rule of Law), and institutionally dependent concepts, such as 'access to justice'. So far as I know, he did not use the terms 'environmental justice' or 'transitional justice'. He treated questions about our duties to animals, endangered species, trees, and the environment as falling outside the scope of his theory of justice as fairness. See further below note 75 .

43 PLL at 40.

44 Twining (2000) at 128-9. There are some important exceptions to the trend towards greater geographical particularity. The field of international ethics, exemplified by Peter Singer, Brian Barry, Onora O’Neill, Martha Nussbaum, Amartya Sen, and Thomas Pogge, addresses transnational issues from a global perspective. There have been lively debates about human rights and cultural relativism, and about universalism versus contextualism. The most politically influential ideas are probably still the ideological assumptions underlying the 'Washington Consensus' which links free market economics to the seductive catchphrase 'human rights, good governance, and democracy'. However, see now the Millennium Development Goals, which have been influenced by other, somewhat different strands of thought including the ideas of Amartya Sen (see Sen (1999)).

45 Twining (2000) at 58-60. Critical legal scholars have quite recently turned their attention to comparative law, international law, and Latin America ('Lat-Crits') and issues of globalisation, but it is too early to assess the significance of these developments.

46 E.g. Nussbaum (2000). 
For many commentators, Rawls' A Theory of Justice has been the almost inevitable starting-point for any contemporary theory of justice. It was natural in the 1960s and 1970s to think of justice in terms of domestic justice within societies, conceived as clearly bounded units. As awareness of 'globalisation' developed and interest in 'international ethics' increased, it was hoped that Rawls would rethink the extension of his basic ideas to the international/transnational sphere and would develop a robust theory of global justice. Unfortunately, Rawls did not fulfil such hopes. His later works mark a retreat into a position that, from a global perspective, is a huge disappointment. $^{47}$

From a global perspective, it is bizarre to find a purportedly liberal theory of justice that rejects any principle of distribution, treats an outdated conception of public international law as satisfactorily representing principles of justice in the global arena, and says almost nothing about radical poverty, the environment, increasing inequalities, and American hegemony (and how it might be exercised), let alone about transitional justice or reparations or other issues that are now high on the global agenda. What had promised to be a progressive critical theory ended up with a position that one of his pupils, Thomas Pogge, concluded amounted to 'arbitrary discrimination in favour of affluent societies and against the global poor' ${ }^{48}$

Fortunately, Pogge has ably defended and refined Rawls' original theory and has substituted his own quite radical theory of international justice and human rights. Mainly by changing one of Rawls' key conceptions - the postulate that justice as fairness is only concerned with the internal ordering of societies conceived as selfcontained units -, he has shown how much of Rawls' scheme can be converted from a parochial and quite conservative theory into one that could be of real value in providing a moral basis for a substantial critique and redesign of supranational and international institutions. Rawls' core ideas for a practical theory aimed at providing a criterion of justice for basic institutions can be applied to the global system with a few adjustments along the following lines: We live in an interdependent world, in which all are involved and from which 'we cannot just drop out'. There are no self-contained national societies in the modern world, nor are there likely to be. The only closed social system is humanity at large. ${ }^{49}$ A theory of justice for any other kind of association, including the nation state, is dependent on background principles

47 A sample of critical reviews includes Buchanan (2000) (this is part of a generally critical symposium on The Law of Peoples); Kuper (2000); Tasioulas (2002a); and Singer (2004) at 176-80. For a partial defence, see Tasioulas (2005).

48 Pogge (2002) at 108.

49 Pogge talks of 'the global system' (about which I have reservations); not much would be changed by substituting some looser term, such as humankind. He envisages an extension of the Rawlsian model of a hierarchy of associations acting as systems within systems, whereas the picture that I have suggested is a much more complex one of overlapping and cross-cutting semi-autonomous social spheres operating in a complex global context. However, we agree on the point that any theory of justice has to be set in a broad context which prescribes background rules and constraints for more localised spheres of justice. 
or 'ground rules' formulated at the global level. ${ }^{50}$ This is a world of widespread deprivations and disadvantages, many of which have been promoted by existing transnational institutions. One test of basic institutions is the benefits and burdens they engender. The position of the least advantaged is one important measure of just institutions. It is highly probable that improved global institutions would help to alleviate at least some of the existing deprivations and disadvantages of the worst off. Rawls' two principles (modified and extended to give more weight to social and economic needs) and some of his basic ideas - such as the veil of ignorance, search for an overlapping consensus, the individual as the ultimate unit of justice ${ }^{51}-$ and the basic structure are more coherently applicable to 'the global system' than to artificially bounded societies or states, not least because 'all institutional matters, including the ideal extent of national sovereignty, are now systematically addressed within a single framework'. ${ }^{2}$ On the basis of this neo-Rawlsian approach, Pogge concludes that 'our current global institutional scheme is unjust, and as advantaged participants in this order we share a collective responsibility for its injustice. ${ }^{53}$

For present purposes, it is sufficient to make three points about the significance of Pogge's contribution: first, as a disciple of Rawls he has modified and refined the ideas in ways that many may agree represent an improvement on $A$ Theory of Justice. Secondly, as an increasingly sharp critic of Rawls he has substituted a theory of international justice that is radically different from Rawls' own late effort, but which is nevertheless Rawlsian in spirit. Thirdly, by confronting in detail the facts of global poverty and some of the political practicalities it involves he has engaged with one of the major issues of our age from the point of view of a philosopher, who believes that abstract ideas are important in addressing practical problems. Whether or not one agrees with all of his arguments, the message is clear: if you are concerned about justice in relation to world poverty, read World Poverty and Human Rights rather than The Law of Peoples. In the present context, however, Pogge's approach has two limitations. First, it is highly focused on only one aspect of global justice, radical poverty, and he touches only incidentally on environmental issues. Pogge adopts a

50 Rawls follows Kant (1795) in rejecting a centralised regime of world government on the ground that it would be either a global despotism or else an unstable and fragile empire torn by civil strife (Rawls (1993) at 54-5). This is a quite different point from the argument that the justice of any domestic political order needs to be set in a wider, transnational or global context, especially as societies become increasingly interdependent. Cf. Pogge (1989) at 255-6.

51 Pogge (1989) Ch. 2, defends Rawls against charges of atomism, that is, of treating individuals as if they are socially and politically isolated and self-sufficient; but Rawls does treat the individual human being as the ultimate moral unit.

52 Ibid. at 258.

$53 \mathrm{Ibid}$. at 277. Cf. Ibid. at 36: 'It is not easy to convince oneself that our global order, assessed from a Rawlsian perspective, is moderately just despite the widespread and extreme deprivations and disadvantages it engenders. Even if we limit our vision to our advanced Western society, it is hardly obvious that the basic institutions we participate in are just or nearly just. In any case, a somewhat unobvious but massive threat to the moral quality of our lives is the danger that we will have lived as advantaged participants in unjust institutions, collaborating in their perpetuation and benefiting from their injustice.' 
thin interpretation of human rights for the specific purpose of arguing that present institutional arrangements contribute to poverty. Secondly, Pogge is constructing an argument that is intended to have a broad appeal that transcends a range of positions. He does not rely on arguments that we owe a positive duty to help the worst off, as Singer does, but restricts his argument to a negative duty not to maintain institutions that maintain or contribute to radical poverty. ${ }^{54}$

\subsection{The salience of human rights discourse: the only show in town?}

Some commentators claim that the language of human rights has become the dominant mode of moral discourse of the last fifty years, edging out moral tropes such as distributive justice, the common good, and solidarity. ${ }^{55}$ Such claims to dominance and universality seem to me to be overstated. It is true that, after 'the collapse of communism', symbolised by the fall of the Berlin Wall, some former Marxist and socialist intellectuals adopted the discourse of human rights. It is also the case that enormous advances have been made in the development of an international regime of human rights law and that domestic bills of rights have also proliferated in the past twenty-five years. ${ }^{56}$ Partly as a result, many other interested parties have jumped on the bandwagon. Indeed, one of Baxi's central themes is that human rights discourse has become commodified, professionalised by technocrats, and sometimes hijacked by powerful groups, so that it is in grave danger of losing touch with the experiences of suffering and the needs of those who should be the main beneficiaries - the poor and the oppressed. ${ }^{57}$ More pragmatically, Yash Ghai has argued on the basis of his extensive experience of constitution-making in multi-ethnic societies, that human rights discourse provides a workable framework for negotiating claims between different interest groups, provided that the substance of the claims are not taken too literally. ${ }^{58}$ In other words, human rights is best conceived as a language for expressing claims and arguments rather than as an abstract set of universal standards. Whether rights-based approaches to foreign assistance, development, and ecology are more than passing fashions is an open question. But claims that secular human rights can become a universal moral language are overstated and need to be treated with great

\footnotetext{
54 As Singer has modified his pure utilitarianism in order to broaden the appeal of his argument, Pogge appears to have trimmed his philosophical views in order to persuade a broader political constituency. In reading contemporary writers like Pogge and Singer, it is often difficult to distinguish clearly between their philosophical positions and their more activist concern to persuade broader audiences about their conclusions. From a global perspective, if one accepts belief pluralism as a fact, I suggest that it is important to distinguish between constructing cogent philosophical arguments and advancing persuasive arguments that have a broad appeal and may contribute to workable political agreements among people with different ideologies and potentially conflicting interests. Both are worthy enterprises, but they should be recognised as separate.

55 Baxi (2006) at 1 and Ch. 4. Cf. similar claims made by Conor Gearty (2006) and Henkin (1990).

56 Gearty (2006) at 63-4. $\quad{ }^{57}$ Baxi (2006). discussed in Twining 2006 at n. 2.

58 E.g. Ghai (2000), discussed in Twining (2006).
} 
caution. Let me give just two reasons: First, belief pluralism is a fact and human rights discourse just does not fit easily with the languages and ways of viewing things of the major religions and many other belief systems. For example, Abdullahi An Na'im, in his invaluable attempts to reconcile the values of liberal Islam and of the Universal Declaration of Human Rights, acknowledges that, while some, but not all, of the basic values are compatible, to be persuasive the discourse has to be translated into terms that fit the beliefs and ways of thinking of most Muslims. ${ }^{59}$ Broadly speaking, the language of Islam is not the language of rights. There are also other belief systems that are more comfortable with the language of responsibility, or community, or civic virtue. Critics of the claim that human rights are Western values being imposed on Asian countries and cultures have rightly pointed out that the origin of human rights does not negate its validity, that there is no monolithic Asian culture, that there are many Asian supporters of human rights and civil liberties, and that the 'Asian Values' debate was largely stimulated by dictatorial leaders responding to outside criticism of repressive practices and in the process invoking the right to self-determination. ${ }^{60} \mathrm{Such}$ criticisms are no doubt justified, but the fact remains that the language of Confucianism and many other traditional cultures is different from the language of individual human rights. ${ }^{61}$

A second warning about the expansionist tendencies of human rights talk relates to the scope of human rights. One of the unresolved questions of human rights theory concerns the criteria for distinguishing between appropriate and inappropriate usages of human rights discourse. ${ }^{62}$ In the present context, it is especially important to clarify the relationship between the discourses of justice, human rights and utility. It is worth remembering that Rawls developed his theory of justice as fairness to limit the scope of utilitarianism, not to reject all consequentialist arguments. Rawls also explicitly limited the scope of justice as fairness, allowing for other social values (such as efficiency and economic development) ${ }^{63}$ and repeatedly disclaiming that his theory of justice was a comprehensive theory of human flourishing or the good life. ${ }^{64}$ Furthermore, while acknowledging that humans owe some duties 'to animals and to the rest of nature', he explicitly excluded these from the province of his theory of justice. ${ }^{65}$ It is also important to bear in mind the distinction between using consequentialist arguments instrumentally to work out the details of a deontological approach (as, for example, Aquinas and Finnis have done) and using rights- or justice-based arguments to trump consequentialist ones. ${ }^{66}$

59 E.g. An Na'im (1990) and An Na'im and Deng (1990) and (1992). An Na'im's approach is discussed at length in Twining (2006). See also Lindholm and Vogt (1993).

60 Sen (1997) at 40; Ghai (1993), (1995) and (1998b); and Castellino and Redondo (2006).

61 This is acknowledged by Ghai (1998a). $\quad{ }^{62}$ Griffin (2001), criticised in Tasioulas (2002b).

${ }^{63}$ E.g. Rawls (1971) at $9 . \quad{ }^{64}$ E.g. Rawls (1993) at 11-15.

65 E.g. Rawls (1971) at 17, 505ff, 512; and Rawls (1993) at 245.

${ }^{66}$ Pressure of space precludes doing justice here to the complex issues concerning claims for the relative merits of the language of rights, justice, and utility as rhetorical discourses. 
In pluralist ethical theories, the spheres of human rights, justice, and consequentialism are not coextensive. To put the matter simply: climate change threatens to have catastrophic consequences for all humankind. The fact that most poorer individuals and communities are less well-equipped to deal with the consequences means that the impact will be distributed unjustly. That is an exacerbating, but secondary factor. Similarly, considering environmental issues exclusively from a human rights perspective can have a distorting effect. For human rights discourse tends to be binary: either one has a human right or one does not. Moreover, many human rights set minimum standards in an all-or-nothing way, often not allowing for differences of degree. In the same vein, I suggest that one of the key issues should be to what extent a theory of environmental justice leaves scope for other values and to what extent the language of justice is the most appropriate way of expressing all major concerns about the environment.

\subsection{Universalism and cultural relativism}

Accompanying the recognition of belief pluralism and the rise of evangelical human rights, there has been a resurgence of debates about relativism and universalism. There is a long tradition, especially in regard to human rights, of talking of a divide between universalism and cultural or other relativism. ${ }^{67}$ But there is also a widespread tendency to treat such talk as involving a false dichotomy. Aristotle, and modern Aristotelians such as Gordley and Nussbaum, quite explicitly allow for differences between cultures; they merely insist on the universality of underlying principles. Another universalist, Alan Gewirth, argues that universalism can justify certain kinds of ethical particularism, in the sense that 'one ought to give preferential consideration to the interests of some persons against others, including not only oneself but also other persons with whom one has special relationships' ${ }^{68}$ Similarly, Joseph Raz, a committed universalist, sees 'the universal and the particular to be complementary rather than antagonistic', and argues that: 'At the heart of multiculturalism lies the recognition that universal values are realised in a variety of different ways in different cultures and that they are all worthy of respect. ${ }^{69}$ Indeed, among serious thinkers there seem to be very few strong universalists or extreme cultural relativists. And, of

67 See generally Wilson (1997).

68 Gewirth (1988). 'The ethical particularism with which I am concerned here, then, is confined to preferences for or partiality towards various groups, ranging from one's family and personal friends to larger pluralities of one's community, nation, and so forth.' Ibid. at 286. On utilitarianism and loyalty, see Twining (2000) at 66-7 and 131; on loyalty, see Fletcher (1993).

$69 \mathrm{Raz}$ (1998) at 204 (citing earlier writings). Raz acknowledges that morality can change, but not radically, but only against an unchanging background of continuing moral principles that explain the change. 'Since... radical moral change is impossible, it follows that social relativism is untenable.' Raz (1999) at 180. An even stronger universalist might argue that it is not fundamental moral principles that change, but our understandings of them. 
course, 'relativism' is a highly ambiguous concept. ${ }^{70}$ There is a widespread view that polarising the debate merely serves to obscure a complex variety of issues that need to be differentiated.

\subsection{Anthropocentric and ecocentric views in normative jurisprudence}

A topic not much discussed in the mainstream jurisprudential literature, but prominent in the environmental literature, is the distinction between anthropocentric and ecocentric perspectives. For the sake of brevity, one can borrow a quite stark definition of these terms:

An anthropocentric action is taken to be one in which the reason to act is the provision of a benefit to human beings. An ecocentric action is taken to be one in which the reason to act is the provision of a benefit to the environment. ${ }^{71}$

The extent to which the canonical jurists seem to be anthropocentric is quite striking. Utilitarianism focuses on the pains and pleasures of human beings, but Bentham famously extended the application of utility to all sentient beings. ${ }^{72}$ Peter Singer followed him. ${ }^{73}$ So utilitarianism seems to be committed to protect non-sentient nature only insofar as it bears on the pleasures and pains of sentient beings. Human rights discourse is anthropocentric on its face; ascribing rights to trees or plants or artefacts is generally acknowledged to be an extension, which many feel is analytically dubious. Rawls' justice as fairness is a virtue of social institutions, meaning human institutions. Dworkin's basic notion of 'equal concern and respect' relates to human beings only. ${ }^{74}$ Similarly, concern for the interests of future generations is generally taken to mean future human beings. However, on closer examination, these jurists, while focusing on human rights and interests, do not necessarily exclude all eco-centric reasons. Rawls, for example, acknowledges that we have moral duties in respect of animals and nature, but he treats these as falling outside his theory of justice as fairness as a political conception, which only applies to those who have a moral personality. ${ }^{75}$ Similarly, Peter Singer may have given a different impression in Animal Liberation, but, when he was accused of 'speciesism' in limiting his argument

70 Haack (1998) Ch. 9.

71 Donnelly and Bishop (2007) arguing that 'new' Natural Law, as exemplified by Finnis and George, is necessarily anthropocentric, because it does not purport to derive natural law principles from human nature, thereby avoiding criticism concerning the naturalistic fallacy. On the other hand, 'traditional Natural Law' can provide support for ecocentrism in that it can be based on the idea of human nature being but one part of the general natural environment.

72 'The question is not: can they reason? Nor, can they talk? but can they feel?' Bentham (1789/1970) at $283 \mathrm{n}$.

73 Singer (1990).

74 See, however, the discussion of the Snail Darter case in Dworkin (1986) at 20-3.

75 Rawls (1971) at 504-12, especially 512. Rawls (1993) at 20, 244ff. '[T] he status of the natural world and our proper relation to it is not a constitutional essential or a basic question of justice, as these questions have been specified [in Rawls' theory]. It is a matter in regard to which citizens can vote their non-political values and try to convince other citizens accordingly. The limits of public reason do not apply.' Rawls (1993) at 
to sentient beings, he hotly denied the charge. ${ }^{76}$ Singer argues that to restrict 'rights' to human rights and to restrict utility to sentient beings are not arbitrary boundaries, but such restrictions do not rule out the possibility of extending the circle of our moral concern to other aspects of nature on the basis of other moral principles. Singer has difficulty with the philosophical basis of a non-speciesist ethic, such as Rolston's 'respect for life'. Singer does not put forward an alternative basis. Instead, he extends the range of anthropocentric reasons for preserving the environment, by emphasising aesthetic, scientific, and recreational values of preserving natural ecosystems and argues that the environment should be preserved for future generations, not least to allow them to choose how to deal with it. ${ }^{77}$ As I read him, Singer cares passionately about the environment; the main reasons he advances for valuing the environment are ultimately anthropocentric, but he leaves the door open for the evolution of a philosophically coherent ecocentric ethos, which in his view has yet to be achieved.

To sum up: it is undoubtedly the case that nearly all of the thinkers that I have discussed have an anthropocentric focus. However, it would be a mistake to infer from this that they are indifferent to environmental concerns or that they treat ecocentric reasons as invalid. Most do, however, seem to take the position that ecocentric reasons fall outside the scope of the mainstream discourses of utility, human rights, and justice as fairness. ${ }^{78}$

\section{Conclusion}

The French philosopher, Jacques Maritain, who played a significant role in the preparation of the Universal Declaration of Human Rights, relates a story of someone expressing amazement that proponents of opposed ideologies had reached agreement on a list of rights: 'Yes, they replied. We agree on these rights, providing we are not asked why. ${ }^{79}$ Maritain drew a sharp distinction between 'practical conclusion' and 'rational justification' ${ }^{80} \mathrm{He}$ had a well-developed Thomist conception of dignity as part of his theory of Natural Law. But, to use a later distinction, he supported the use of the concept in the draft Declaration, but argued strongly for leaving the conception undefined. $^{81}$

246. Rawls also enumerates a number of examples in which, because the treatment of animals and other aspects of nature bear on human interests, political values are involved. Ibid. at 245 .

76 Rolston (1999); Singer's response in the same volume is at 327-32. His position on environmental ethics is set out at greater length in Singer (1993) Ch. 10.

77 See note 75 above.

78 In earlier versions of this paper, there were sections on ecumenical arguments and ius humanitatis, but these have been cut for reasons of space.

79 Maritain (1954) at $70 . \quad 80$ Ibid. Ch. IV.

81 On dignity as a 'placeholder concept', see McCrudden (2008). 
When Jacques Maritain drew a quite sharp distinction between philosophical arguments and pragmatic approaches to human rights, he was not saying that philosophy was unimportant. Rather, like Rawls and many twentieth-century philosophers, he emphasised that belief pluralism is a social fact that has implications both for philosophy and for the practical politics of coexistence and cooperation. Maritain's strategy in respect of rights suggests that we need coherent philosophies, ecumenical arguments, and a willingness to negotiate working agreements patiently, in detail, in a pragmatic fashion accepting the need to compromise. ${ }^{82}$ Concepts like justice, utility, and rights all have a role to play in constructing such arguments and negotiations.

In concluding, six salient themes:

1. When using G-words, it is best to remember that nearly all processes of so-called 'globalisation' operate primarily at sub-global levels.

2. From a global perspective, if one adopts a reasonably broad conception of law, it is almost inevitable that the picture is one of great variety and complexity, involving multiple levels, non-state law, legal pluralism, cross-level diffusion, complex kinds of interlegality, and largely surface homogenisation and convergence. With due respect to Thomas Friedman, so far as law is concerned, the world is not yet flat. $^{83}$

3. At first sight, many of our canonical jurists may seem out of place in a postWestphalian world. However, a younger generation of jurists is developing new kinds of general jurisprudence, which builds on their predecessors as well as stabbing them in the back: Tamanaha fillets Hart; Pogge transfers Rawlsian justice to the world stage more convincingly than Rawls; Singer modernises Bentham; and Santos post-modernises Weber and Marx.

4. Most post-Enlightenment moral theories in the West are avowedly secular. Human rights is sometimes conceived of as a critical secular theology or a theory of values for a Godless Age. But, from a global perspective, most of the world is going through a period of religious revival. Believers and non-believers alike need to be persuaded about global policies.

5. Most Western jurists have an anthropocentric focus. It does not follow that they are indifferent to environmental concerns nor that they treat ecocentric reasons as invalid. Most do, however, seem to take the position that ecocentric reasons fall outside the scope of the mainstream discourses of utility, human rights, and justice as fairness.

6. One of the challenges in approaching environmental issues is to what extent a theory of environmental justice leaves scope for other values and to what extent the language of justice is the most appropriate way of expressing all major concerns about the environment.

\footnotetext{
82 On ecumenical arguments, see note 54 above. $\quad{ }^{83}$ Friedman (2005).
} 


\section{Bibilography}

An Na'im, A., 1990. Toward an Islamic Reformation: Civil Liberties, Human Rights and International Law. Syracuse, NY: Syracuse University Press.

(ed.), 1992. Human Rights in Cross-Cultural Perspectives: Quest for Consensus. Philadelphia: Pennsylvania University Press.

An Na'im, A., and Deng, F. (eds.) 1990. Human Rights in Africa: Cross-Cultural Perspectives. Washington, DC: Brookings Institution.

Baxi, U., 2006. The Future of Human Rights. 2nd edn, New Delhi: Oxford University Press.

Bentham, J., 1789/1970. An Introduction to the Principles of Morals and Legislation. ed. J. H. Burns and H. L. A. Hart. Collected Works. Oxford: Oxford University Press.

1806-9. Principles of International Law, Works, vol. 2. Bowring edition, 1837-43.

Blomley, N., 1994. Law, Space and the Geographies of Power. New York: Guilford Press.

Buchanan, A., 2000. 'Rawls's Law of Peoples: Rules for a Vanished Westphalian World'. 110 Ethics 697.

Castellino, J., and Redondo, E. D., 2006. Minority Rights in Asia. Oxford: Oxford University Press.

Commission on Global Governance, 1996. Our Global Neighbourhood. Oxford: Oxford University Press.

Dinwiddy, J., 2004. Bentham: Selected Writings of John Dinwiddy. W. Twining (ed.). Stanford: Stanford University Press.

Donnelly, B., and Bishop, P., 2007. 'Natural Law and Econcentrism'. 19 Journal of Environmental Law 89.

Dworkin, R., 1986. Law's Empire. London: Fontana.

Economides, K., 1996. 'Law and Geography: New Frontiers', in Philip Thomas (ed.), Legal Frontiers. Aldershot: Dartmouth.

Fletcher, G., 1993. Loyalty. New York: Oxford University Press.

Foster, N. (ed.) 2006. 'A Fresh Start for Comparative Legal Studies', Symposium on Patrick Glenn's Legal Traditions of the World (2nd edn), in 1 Journal of Comparative Law 100.

Friedman, T. L., 2005. The World is Flat. New York: Farrar, Straus and Giroux.

Gearty, C., 2006. Can Human Rights Survive? Cambridge: Cambridge University Press.

Gewirth, A., 1988. 'Ethical Universalism and Particularism'. 85 Journal of Philosophy 283.

Ghai, Y., 1993. 'Asian Perspectives on Human Rights'. 23 Hong Kong Law Journal 342.

1995. 'The Politics of Rights in Asia', in G. P. Wilson (ed.), Frontiers of Legal Research. Chichester:

Chancery Law Publishing.

1998a. 'Rights, Duties and Responsibilities', in J. Caughelin, P. Lim, and B Mayer-Konig (eds.), Asian Values: Encounter with Diversity. London: Curzon Press, Ch. 2.

1998b. 'Human Rights and Asian Values'. 9 Public Law Review 168.

2000. 'Universalism and Relativism: Human Rights as a Framework for Negotiating Interethnic

Claims.' 21 Cardozo Law Review 1095.

Giddens, A., 1990. The Consequences of Modernity. Stanford: Stanford University Press.

Glenn, P., 2004. Legal Traditions of the World: Sustainable Diversity in Law. 2nd edn, Oxford: Oxford University Press.

Griffin, J., 1996. Value Judgement. Oxford: Oxford University Press. 
2001. 'Discrepancies Between the Best Philosophical Account of Human rights and the International Law of Human Rights'. Presidential Address, Proceedings of the Aristotelian Society 1.

Haack, S., 1998. Manifesto of a Passionate Moderate. Chicago: University of Chicago Press.

Hampshire, S., 1989. Innocence and Experience. London: Allen Lane.

Hart, H. L. A., 1982. Essays on Bentham. Oxford: Oxford University Press.

1983. 'Problems of the Philosophy of Law', in Essays in Jurispudence and Philosophy. Oxford:

Oxford University Press.

Henkin, L., 1990. The Age of Rights. New York: Columbia University Press.

Holder, J., and Harrison, C. (eds.) 2003. Law and Geography. Oxford: Oxford University Press.

Huxley, A. (ed.), 2002. Religion, Law and Tradition. London: RoutledgeCurzon.

Jamieson, D. (ed.), 1999. Singer and His Critics. Oxford: Blackwell.

Jenkins, P., 2002. The Next Christendom. Oxford: Oxford University Press.

Kant. I., 1795/1970. Perpetual Peace in Political Writings. ed. H. Reiss, Cambridge: Cambridge University Press.

Klug, F., 2000. Values for a Godless Age: The Story of the United Kingdom's New Bill of Rights. London: Penguin Books.

Kuper, A., 2000. 'Rawlsian Global Justice: Beyond the Law of Peoples to a Cosmopolitan Law of Persons'. 28 Political Theory 640.

Lessig, L., 2002. The Future of Ideas: The Fate of the Commons in a Connected World. New York: Random House.

Lindholm, Tori, and Vogt, Kari (eds.), 1993. Islamic Law Reform and Human Rights: Challenges and Rejoinders. Copenhagen and Oslo: Nordic Human Rights Publications.

MacIntyre, A., 1985. After Virtue. 2nd edn, London: Duckworth.

Maritain, J., 1954. Man and the State. ed. Richard O'Sullivan, London: Hollis and Carter.

McCrudden, C., 2008. 'Human Dignity and Judicial Interpretation of Human Rights'. 20 European Journal of International Law 1.

Miztal, Bronislaw, and Sharpe, Anson (eds.), 1992. Religion and Politics in Comparative Perspective: Revival of Religious Fundamentalism in East and West. Westport, CT: Praeger.

Nussbaum, M., 2000. Women and Human Development: The Capabilities Approach. Cambridge: Cambridge University Press.

Pearl, David, and Menski, Werner, 1998. Muslim Family Law. 3rd edn, London: Sweet \& Maxwell.

Pogge, T., 1989. Realizing Rawls. Ithaca: Cornell University Press.

2001. 'Rawls on International Justice'. 51 Philosophical Quarterly 246.

2002. World Poverty and Human Rights. Cambridge: Polity Press.

2005. 'Real World Justice'. 9 Journal of Ethics 29.

Rawls, J., 1971. A Theory of Justice. Cambridge, MA: Harvard University Press.

1980. 'Kantian Constructivism in Moral Theory' (reprinted in Rawls (1999a)).

1985. 'Justice as Fairness: Political, Not Metaphysical' (reprinted in Rawls (1999a) Ch. 18)

1987. 'The Idea of an Overlapping Consensus' (reprinted in Rawls (1999a) Ch. 20).

1993. Political Liberalism. New York: Columbia University Press.

1998. 'Commonwealth Interview with John Rawls' (reprinted in Rawls (1999a) at 616).

1999a. Collected Papers, ed. S. Freeman. Cambridge, MA: Harvard University Press.

1999b. The Law of Peoples. Cambridge, MA: Harvard University Press. 
Raz, J., 1994. Ethics in the Public Domain. Oxford: Clarendon Press. 1998. 'Multiculturalism'. 11 Ratio Juris 193.

1999. Engaging Reason. New York: Oxford University Press.

Rogers, B., 1999. 'Portrait: John Rawls', Prospect, Issue 42, June.

Rolston III, H., 1999, 'Respect for Life: Counting What Singer Finds of No Account', in Dale Jamieson (ed.), Singer and His Critics. Oxford: Blackwell, at 247-68.

Rorty, R., 1993. 'Human Rights, Rationality and Sentimentality', in Stephen Shute and Susan Hurley (eds.), On Human Rights. New York: Basic Books.

Sachs, J., 2005. The End of Poverty. London: Penguin.

Santos, Boaventura de Sousa, 1995. Toward a New Common Sense. London: Routledge.

2002. Toward a New Legal Common Sense: Law, Globalization and Emancipation. 2nd edn, London: Butterworths Lexis Nexis.

Sen, Amartya, 1997. 'Human Rights and Asian Values: What Lee Kuan Yew and I Peng Don't

Understand About Asia', The New Republic, 14 and 21 July, 33-40. 1999. Development as Freedom. New York: Knopf.

Singer, P., 1972. 'Famine, Affluence and Morality'. 1 Philosophy and Public Affairs 229-43 (variously reprinted).

1983. The Expanding Circle. Oxford: Oxford University Press.

1990. Animal Liberation. 2nd edn, New York: Random House.

1993. Practical Ethics. 2nd edn, Cambridge: Cambridge University Press.

2004. One World. 2nd edn, New Haven: Yale University Press.

Stiglitz, J., 2002. Globalization and Its Discontents. London: Allen Lane.

Stone, J., 1946. The Province and Function of Law. Cambridge, MA: Harvard University Press.

Tamanaha, B., 2001. A General Jurisprudence of Law and Society. Oxford: Oxford University Press.

Tasioulas, J., 2002a. 'From Utopia to Kazanistan: John Rawls and the Law of Peoples'. 22 Oxford Journal of Legal Studies 367.

2002b. 'Human Rights, Universality and the Values of Personhood: Retracing Griffin’s Steps'. 10

European Journal of Philosophy 79.

2005. 'Global Justice Without End'. 36 Metaphilosophy 3.

Twining, W., 1997. Law in Context: Enlarging a Discipline. Oxford: Oxford University Press. 2000. Globalisation and Legal Theory. London: Butterworths.

2003a. The Great Juristic Bazaar. Aldershot: Ashgate.

2003b. 'A Post-Westphalian Conception of Law' 37 Law and Society Review 199.

2003c. 'The Province of Jurisprudence Re-examined', in Catherine Dauvergne (ed.), Jurisprudence in an Interconnected Globe. Aldershot: Ashgate, Ch. 2.

2005a. 'Have Concepts, Will Travel: Analytical Jurisprudence in a Global Context'. 1 International Journal of Law in Context 5.

2005b. 'General Jurisprudence', in M. Escamilla and M. Saavedra (eds.), Law and Justice in Global

Society. Granada: University of Granada, World Congress of Philosophy of Law and Social Philosophy.

2005c. 'Diffusion of Law: A Global Perspective'. 49 Journal of Legal Pluralism 1.

2005d. 'Social Science and Diffusion of Law'. 32 Journal of Law and Society 203.

2006. 'Human Rights: Southern Voices'. 11 Review of Constitutional Studies 203.

2008. General Jurisprudence: Understanding Law from a Global Perspective. Cambridge: Cambridge

University Press. 
Wilson, R. A. (ed.), 1997. Human Rights, Culture and Context. London: Pluto Press.

Woodman, G., 2003. 'Why There Can Be No Map of Law', in Rajendra Pradhan (ed.), Legal Pluralism and Unofficial Law in Social, Political, and Economic Development, XIIIth International Congress of Commission on Folk Law and Legal Pluralism, Kathmandu, at 38392.

2006. 'The Chthonic Legal Tradition - Or Everything That Is Not Something Else'. 1 Journal of Comparative Law 123. 